Ivana Vuksanović

Univerzitet umetnosti u Beogradu

Fakultet muzičke umetnosti

vuksanovici@fmu.bg.ac.rs
DOI: https://doi.org/10.18485/slovenika.2020.6.1.2

UDK: 782.1(497.11)

792.54.091(497.11)

Naučni članak

\title{
Opera Pokondirena tikva Mihovila Logara i zasnivanje komičnog muzičko-scenskog žanra u Srbiji ${ }^{1}$
}

\section{Sažetak}

Ustanovljenje muzičko-scenskog komičnog žanra u Srbiji dogodilo se tek u drugoj polovini XX veka, tačnije 1956. godine, pojavom opere Pokondirena tikva iz pera kompozitora Mihovila Logara (1902-1998), a prema istoimenoj komediji Jovana Sterije Popovića. Time je na srpskoj operskoj sceni premošćen vremenski jaz od preko dva veka od pojave prve komične opere $u$ Italiji. Posle 65 godina od nastanka sagledava se značaj ovog žanra u kulturno-umetničkom životu Srbije prošlog veka, stilski i dramaturški dometi Logareve Pokondirene tikve, istorijat izvođenja ove opere i njen uticaj na dalji razvoj žanra u Srbiji. U tekstu se analitički razmatraju mehanizmi Logarevog muzičkog humora, sa posebnim osvrtom na odnos teksta i melodije vokalne deonice, kao i na ulogu orkestracije. Uprkos svojim kompozicionotehničkim i ekspresivno-humornim kvalitetima, Logareva opera nije uspela da se nametne domaćoj publici čak ni kroz savremenije režije i adaptacije, te se $\mathrm{u}$ tekstu kritički razmatraju sudbina Pokondirene tikve i recepcija ove opere tokom druge polovine veka kao posledica repertoarske politike srpskih operskih institucija i statusa humora u domaćoj muzičko-scenskoj umetnosti.

Ključne reči: Mihovil Logar, bufo opera, Pokondirena tikva, muzički humor, recepcija

\footnotetext{
${ }^{1}$ Rad je napisan kao deo projekta Identiteti srpske muzike u svetskom kulturnom kontekstu Katedre za muzikologiju Fakulteta muzičke umetnosti u Beogradu. Projekat podržava Ministarstva prosvete, nauke i tehnološkog razvoja Republike Srbije (evidencioni broj 177019).
} 
Ustanovljenje muzičko-scenskog komičnog žanra u Srbiji dogodilo se tek u drugoj polovini XX veka. Njegovo kasno utemeljenje posledica je, reklo bi se, prirodnog puta koji je vodio od romantičarskog komada s pevanjem u XIX veku, preko osvajanja osnovnih elemenata opersko-scenske dramaturgije $u$ romantičarskim operama Stanislava Biničkog i Isidora Bajića početkom prošlog veka, do primene lajtmotivske tehnike u zrelim operskim dramama Petra Konjovića i Stevana Hristića tokom prve polovine veka. Uprkos tome što je u umetničkom, a naročito književnom kontekstu prošlog veka komediografski žanr bio vrlo popularan, a produkcija solidnog kvantiteta i visokog kvaliteta, komična opera nije uspevala da se nametne kao izazov za muzičke stvaraoce, niti je uspevala da se značajnije afirmiše na repertoarima operskih institucija u Srbiji.

Intenzivniji razvoj muzičko-scenskog žanra u Srbiji bio je podstaknut osnivanjem beogradske Opere 1920. godine, podizanjem profesionalnog nivoa muzičara, izvođenjem opera italijanskih verista i kompozitora nacionalnih škola, kao i gostovanjima stranih operskih pevača. Time se ujedno postepeno i „vaspitavao“ operski ukus domaće publike. U prvoj polovini veka tematika opera je mahom bila nacionalnoistorijski usmerena, pa je shodno tome i muzika bila pretežno romantičarske provenijencije, sa znatnim osloncem na folklor i povremenim iskliznućima ka impresionizmu, verizmu i ekspresionizmu.

U takvom, nacionalno-romantičarsko-folklornom kontekstu i bez ozbiljnije muzičko-scenske tradicije, humora u savremenom smislu te reči nije ni bilo. Poistovećen sa vedrim raspoloženjem, uglavnom je napajao folklorne žanr-scene u strukturi opera. U ovakvu sliku se ubrajaju i dve komične opere u tri čina izvedene 1951. godine u beogradskom Narodnom pozorištu: narodna opera Seljaci Petra Konjovića i Nevjesta od Centingrada Krešimira Baranovića. Dok je prva nastala prema tekstu popularnog pozorišnog komada Đido Janka Veselinovića, druga je rađena prema noveli Turci idu Augusta Šenoe. Ne samo tematikom, koja svedoči o prisutnoj vezi sa romantičarskom tradicijom, već i muzičkim izrazom koji prati zaplete i njihovo srećno razrešenje, ove opere ne pokazuju značajan iskorak i postupke moderne persiflaže. Konjović sasvim eksplicitno navodi Mocarta kao uzora pri komponovanju svoje „narodne“ opere, što je rezultiralo komunikativnim muzičkim jezikom i pročišćenom fakturom dela. S druge strane, u odnosu prema folklornoj tematici (i literarnoj i muzičkoj) ne postoji kritička distanca, koja je neophodna za humor, odnosno neko značajnije iskliznuće iz područja konven- 
cijama i iskustvom očekivanog. Konjovićevim Seljacima nedostaju brzina akcije i brio svojstven bufo operi, ali je zato muzičkim izrazom bila bliska široj domaćoj publici i „ukazuje na potrebu da se u muzici ponovo osvoji veselost“" (Milin 1998, 101).

Pojavom Logareve Pokondirene tikve (1956) na srpskoj operskoj sceni, premošćen je jaz od preko dva veka od pojave prve komične opere u Italiji. Domaći muzikolozi s pravom ističu da je više paradoksalnih činjenica vezano za taj značajan trenutak $u$ istoriji srpske muzike. Činjenica je da je Jovan Sterija Popović bio jedan od najpopularnijih pozorišnih pisaca, a da nijedan njegov komad nije bio uobličen kao komad s pevanjem. Iako je produkcija komičnih žanrova u srpskoj književnosti bila vrlo živa, a sklonost srpske pozorišne publike prema komičnim komadima bila očigledna, nijedan srpski veliki komediograf (Jovan Sterija Popović, Kosta Trifković, Branislav Nušić) nije privlačio pažnju domaćih muzičkih stvaralaca. Poznato je i da je Nušić bio libretista za opere Na uranku Stanislava Biničkog i Knez Ivo od Semberije Isidora Bajića, da je Sterija bio autor nedovršenog teksta za operu koju je nazvao Postanak srbskog carstva, ali da nikada nijedan od njih dvojice nije pisao libreto za komičnu operu. Stoga je Logareva opera Pokondirena tikva jedinstven slučaj u srpskoj muzici; ne samo da je prva komična opera nastala na tlu tadašnje Jugoslavije prema tekstu jednog srpskog komediografa ${ }^{2}$ već je i jedini primer čiste bufo opere u srpskoj scenskoj muzici. Poseban kuriozum jeste i činjenica da je prva srpska bufo opera sa tematikom iz vojvođanske provincije XIX veka nastala iz pera kompozitora koji je bio „po majci Hrvat, po ocu Slovenac, po nacionalnom osećanju Jugosloven, po temperamentu Primorac, po srcu i mestu stalnog i životnog boravka ni došljak ni slučajni namernik, već Beograđanin“ (Zdravković 2008, 125), jedan od mnogih „stranih“ muzičara (slovenačkih, hrvatskih, čeških, ruskih, francuskih) koji su u srpsku muziku uneli duh evropskog muzičkog kosmopolitizma. Logar je takođe jedan od retkih domaćih kompozitora (uz Konstantina Babića i Vojislava Kostića) u čijoj se muzičkoj poetici humor prepoznaje kao spiritus movens.

\footnotetext{
${ }^{2}$ Operete i „vesele opere“ nastale krajem XIX veka i tokom prve polovine XX veka - Vračara Davorina Jenka, Veseli mornari Roberta Tolingera, Tigar Petra Stojanovića - pisane su prema tekstovima stranih autora. Narodne opere Začarana vodenica (1946) Svetomira Nastasijevića i Seljaci (1951) Petra Konjovića, iako pisane prema tekstovima srpskih autora (Nastasijevićeva opera prema pripoveci Milovana Glišića, a Konjovićeva prema komadu Đido Janka Veslinovića i Dragomira Brzaka), nemaju dramaturgiju i zaplet komičnih opera (o tome v. više u: Pavlović 1995).
} 


\section{Istorija opere Pokondirena tikva Mihovila Logara}

Opus Mihovila Logara bogat je raznovrsnim žanrovima, ali je posvećenost scenskom izrazu i naročito operskom žanru konstanta njegovog stvaralaštva i kompozitorova distinktivna crta u odnosu na njegove savremenike. Logar je dugo tražio inspirativni, odgovarajući tekstualni predložak za vedro scensko delo: od zanimljivog pokušaja „šekspirovske simfonije za orkestar i scenu“ (Četiri scene iz Šekspira /1927-31/, gde je drugi stav inspirisan Mletačkim trgovcem, a poslednji je nastao prema Snu letnje noći), preko britke satire svog „zemljaka“ Ivana Cankara, Sablazan u dolini šentflorijanskoj 1938. godine, do Kir Janje Jovana Sterije Popovića 1940. godine. Nažalost, nijedno od ovih dela nije izvedeno na beogradskoj sceni. ${ }^{3} \mathrm{Iz}$ šekspirovske simfonije izvedeni su samo pojedini odlomci na Radio Beogradu, Šentflorijanci su tek tri decenije kasnije doživeli premijeru, ali ne u glavnom gradu, već u Sarajevu, dok je jedina rukopisna partitura opere Kir Janja stradala za vreme bombardovanja 1941. godine u Narodnom pozorištu u Beogradu. Sledeći Logarev izbor bila je Sterijina Pokondirena tikva. Logar je inspiraciju dobio gledajući pozorišnu predstavu u režiji Huga Klajna, sa Ljubinkom Bobić u glavnoj ulozi (1954. godine), a opera je izvedena 20. oktobra 1956. godine povodom proslave 150 -godišnjice rođenja i 100-godišnjice smrti Jovana Sterije Popovića. Pokondirena tikva je posvećena operskoj pevačici Milici Miladinović, ${ }^{4}$ koja je bila nosilac glavne uloge (slika 1); dirigovao je Dušan Miladinović, režirao je Josip Kulundžić, autor scenografije bio je Stanislav Beložanski, a kostimografiju je potpisala Milica Babić.

\footnotetext{
${ }^{3}$ Opera Sablazan u dolini Šentflorijanskoj, za koju je sam kompozitor napisao libreto prema Cankarevom delu, dobila je nagradu Udruženja prijatelja umetnosti „Cvijeta Zuzorić" iste godine kada je i nastala (1938). Beogradska publika je videla ovu muzičku farsu u tri čina na gostovanju sarajevske Opere u okviru prvih Beogradskih muzičkih svečanosti 12. oktobra 1969. godine.

${ }^{4}$ Na partituri opere u izdanju Udruženja kompozitora Srbije (Beograd, 1969) zapisana je i posveta: „Milici Miladinović; za njenu visoku umetnost glasa i glume.“
} 


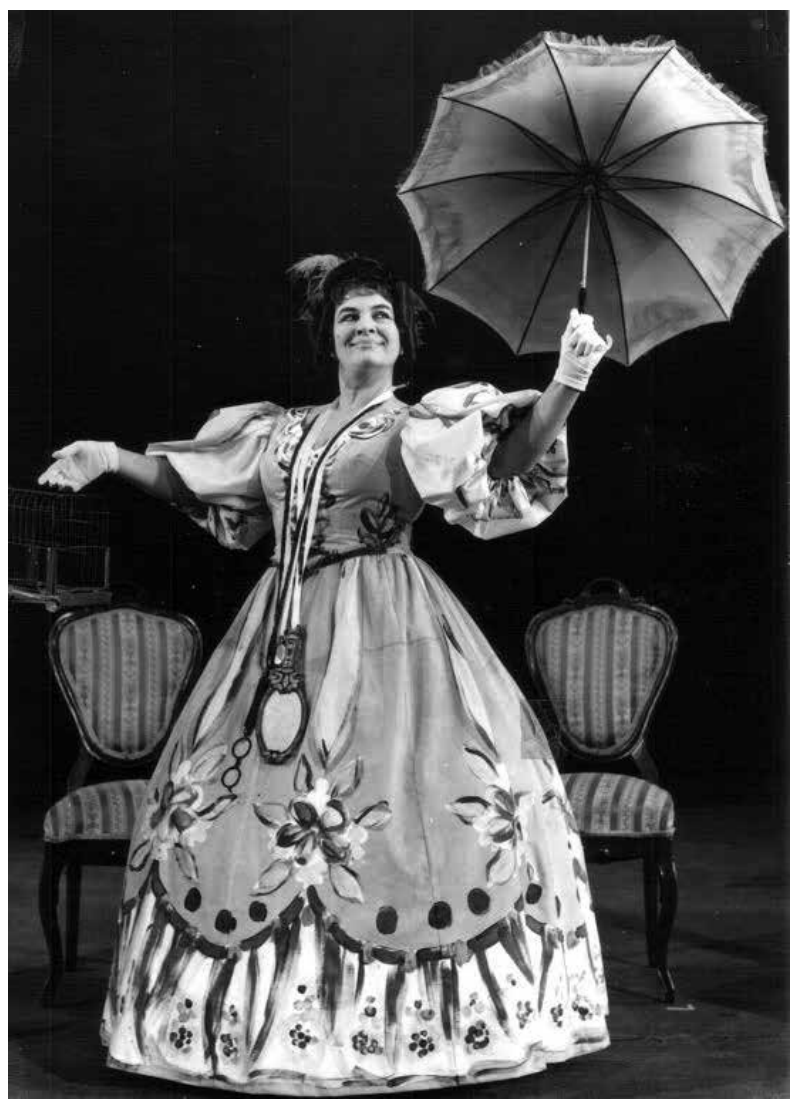

Slika 1 - Milica Miladinović u ulozi Feme, 1956.

Logareva opera je posle premijere doživela još samo sedam izvođenja. Iz pera Marjana Kozine usledio je prvi ozbiljniji prikaz opere u časopisu Zvuk 1957. godine, gde je autor teksta izneo - osim ocene da se radi o delu koje „zadovoljava stroge međunarodne zahteve" (Kozina 1957, 381), pohvala za orkestraciju, realizaciju vokalnih deonica, duhovitost i prijemčivost modernog muzičkog izraza - i blagu kritiku spram trajanja opere i brzine zbivanja na sceni. Kozina je dobronamerno preporučio Logaru redakciju opere $u$ vidu skraćenja i „razređivanja“ partiture, a u cilju isticanja onih momenata koji su publici najdopadljiviji.

Pokondirena tikva je, potom, obnovljena takođe u Narodnom pozorištu u Beogradu 1973. godine (slika 2) sa dodatim baletom na početku drugog čina i „ne baš opravdanim skraćenjima“ (Pavlović 1982, 60). Ovom prilikom operu je režirao Jovan Putnik, za dekor je bio odgovoran Vladimir Marenić, kostime je kreirala Ljiljana Drago- 
vić, a dirigovao je ponovo Dušan Miladinović. U svom prikazu nove postavke opere Mirka Pavlović piše da je za izvođenje ovakve vrste operskog dela „potreban odnegovan i vrlo određen stil izvođenja, kao i vrlo ujednačena grupa izvođača [...] I pored lepih dostignuća pojedinaca, izvođenja u celini nisu imala lakoću, perfekciju, humornu lepršavost, stilsku ujednačenost, pa je delo gubilo od svoje prirodne penušavosti i bljeska“"(Pavlović 1982, 60).

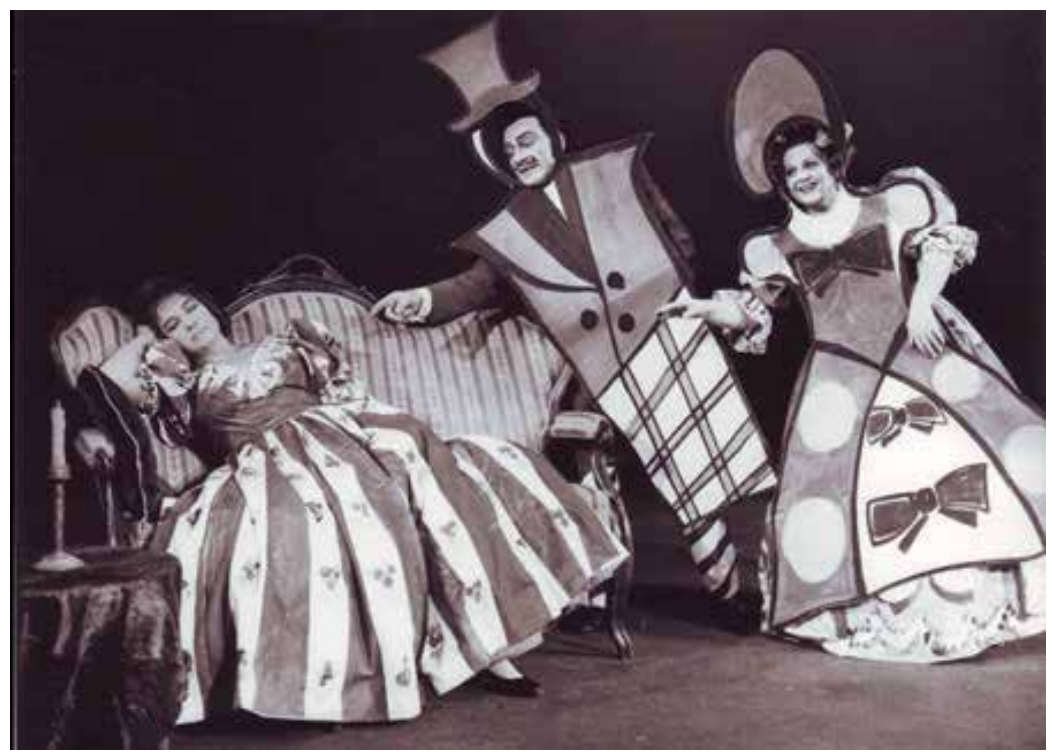

Slika 2 - Milica Miladinović, Jovo Gligorić i Dobrila Bogošević u operi Pokondirena tikva, 1973.

Iako je Logar svoje delo prvobitno namenio Srpskom narodnom pozorištu u Novom Sadu (po porudžbini tadašnjeg direktora Ivana Siliča), Pokondirena tikva je svoju novosadsku premijeru doživela tek četrdeset godina posle nastanka, 3. juna 1993. godine. Reditelj opere bio je Bogdan Ruškuc, a dirigovao je Angel Šurev. Tada je zbog režijskih promašaja, posle svega nekoliko predstava skinuta sa repertoara. Iz Logarevog pisma Mirki Pavlović saznajemo: „Sa druge strane, strašne su vesti iz Novog Sada: Tikva počinje sa daćom - maltene sa mrtvačkim sandukom - i prve su reči na sceni 'Nobles hoću, nobles u mojoj kući!' Režiser si je dozvolio nemoguće skokove - a ne zna muziku; dramski je čovek. Ali kako tako, predstava mora ići na zatvaranju Sterijinog pozorja... Ne poznajem tog famoznog reditelja - kažu da ima dobrih 'caka'. Dirigent je očajan, bez temperamenta. Bio je kod mene svega jedanput“" (Pavlović 2008, 47). Iz Logareve korespondencije sa Miodragom Milanovićem, koji je bio inicijator 
postavke opere u Novom Sadu i tumač Ružičića u operi, očigledno je kompozitorovo neslaganje sa inscenacijom, sa ubacivanjem erotske scene (Milanović 2010), ${ }^{5}$ nedovoljno brzim tempom uvertire i skraćenjem finala prvog čina. Logar u tim pismima zagovara što klasičniji, „goldonijevski“ pristup inscenaciji, a izričito se protivi ubacivanju proznih delova teksta, odnosno zingšpil elemenata.

Sledeći pokušaj postavke opere zabeležio je Operski studio Narodnog pozorišta 2004. godine (režija i klavirska pratnja Aleksandar Kolarević), kada je Pokondirena tikva, uprkos navedenom kompozitorovom stavu, režirana kao zingšpil opera sa originalnim Sterijinim delovima teksta i Logarevim muzičkim numerama i scenama (slika 3). Uzimajući u obzir primedbe Kozine u vezi sa premijernim izvođenjem 1956. godine, ovo je bio zanimljiv rimejk opere koji je ubrzao radnju i skratio trajanje opere. Ipak, u takvoj, možemo reći, „operi s klavirom“ nedostaje raskošna štrausovska, živopisna i duhovita, a pre svega funkcionalna Logareva orkestracija. Posle premijere na maloj sceni Narodnog pozorišta, odigrano je nekoliko predstava u pozorištu „Slavija“, a zatim je i ta verzija nestala sa repertoara. Nova postavka opere usledila je 2006. godine u okviru Sterijinog pozorja (u režiji Gordane Kamenarović i adaptaciji Miodraga Milanovića); i ovoga puta sa klavirskom pratnjom, ali po libretu Huga Klajna.

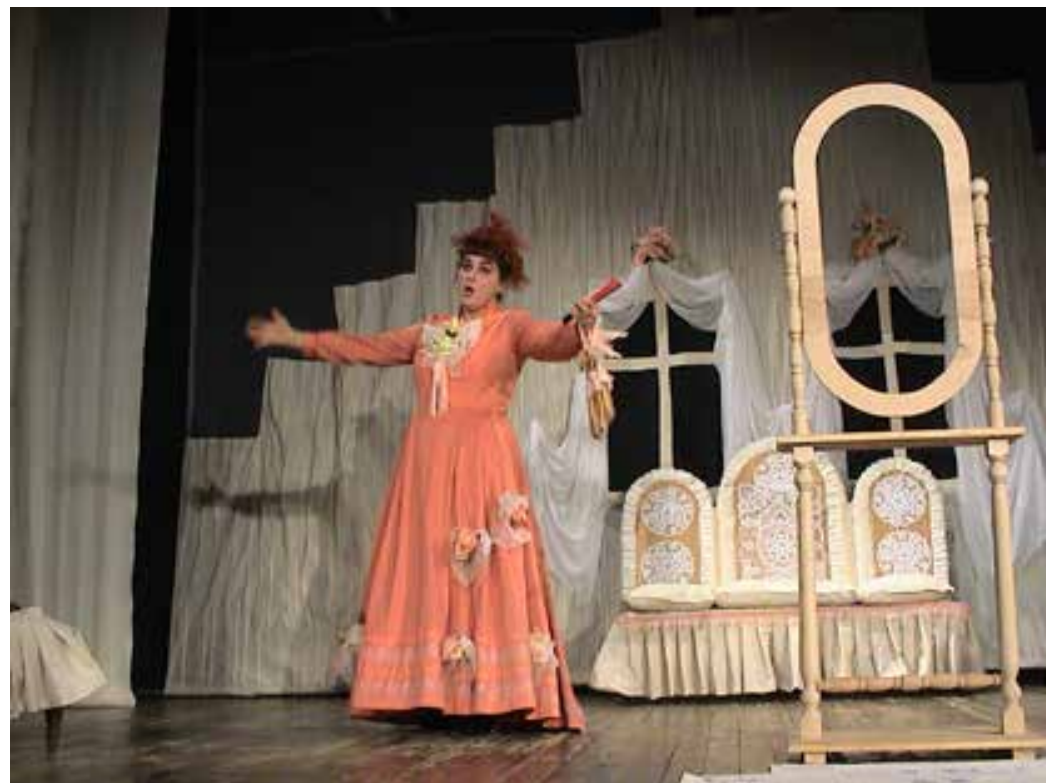

Slika 3 - Ivana Milašinović kao Fema, Pokondirena tikva, 2004.

5 „Apsolutno preinačiti erotsku scenu između Evice i Vase. Ta Sterija se prevrće u grobu na to“ (Milanović 2010). 
Zašto prva srpska bufo opera, nastala prema popularnoj Sterijinoj komediji koja tretira jednu uvek aktuelnu temu i kao delo kompozitora koji je i ekspresivno i kompoziciono-tehnički ubedljivo vladao muzičkim humorom, ne uspeva da se održi na repertoarima srpskih operskih institucija? Da li je problem na strani politike samih institucija, nedovoljne $\mathrm{i} /$ ili neadekvatne kritike ili pak na strani publike, odnosno karakteroloških i kulturoloških crta naroda i podneblja? Pokušaj odgovara na ova pitanja uslediće posle sagledavanja Logareve muzičke realizacije libreta i ključnih komičnih elemenata $\mathrm{u}$ operi. Iz istorijata opere Pokondirena tikva evidentno je više pokušaja da se revitalizuje ovo, za istoriju srpske muzičke scene, izuzetno važno delo; dosadašnja različita čitanja Logareve partiture pružaju nadu da bi ova opera mogla da nađe odavno zasluženo mesto na srpskim operskim scenama. Eventualna slovenačko-srpska koprodukcija dve Logareve komične opere, Sablazan u dolini Šentflorijanskoj i Pokondirena tikva, dodatno bi doprinela međukulturnoj saradnji i komunikaciji, kao i oživljavanju scenskog opusa kompozitora koji je inspiraciju za svoja dela nalazio u komediografskom žanru sa oba jezička i kulturna područja.

\section{Profilisanje likova u operi Pokondirena tikva}

Zajedničku nit Logarevih dotadašnjih scenskih dela, uključujući i balet Zlatna ribica (1950), čine, prema mišljenju Nadežde Mosusove, primese komedije del arte: likovi po uzoru na Arlekina, Kolumbinu, Pantalonea ili Doktora, prerušavanje i pantomimske scene, te duh „pučkog“, italijanskog/mediteranskog teatra (Mosusova 2008, 30-35). Uticaj komedije del arte na naše komediografe - Steriju, Trifkovića i Nušića - nije, naravno, bio direktan, ali se odvijao preko evropskih velikana kao što su Goldoni (Carlo Goldoni), Molijer (Jean-Baptiste Poquelin Moliere) i Marivo (Pierre de Marivaux), čije su komedije igrane u domaćim pozorištima. Naročito je vidan uticaj Goldonijevih komedija, koje je srpska publika još od 1842. godine mogla da prati na scenama pozorišta u Novom Sadu i Beogradu. U Molijerovim komadima, koji su beogradskoj publici bili poznati od 1948. godine, nema eksplicitnih tragova komedije del arte, ali su neka iskustva tog pozorišta prisutna u vidu arhetipskih dramaturških konvencija - veštine zapleta, komičnih situacija i duhovitih replika, scenskih obrta i iznenađenja - ili nekih tipova likova koji bi nas podsećali na Pantalonea, Doktora, ljubavne parove ili brojne varijante slugu. 
Sterijina Pokondirena tikva je, tematski gledano, komedija o ekonomskom uzdizanju zanatlija u Vršcu prve polovine XIX veka. Moglo bi se reći da u ovom delu Sterija poseže za tipično molijerovskim motivom, recimo onim iz Građanina plemića, a to je težnja nižeg sloja tek formiranog građanskog staleža da se domogne viših društvenih slojeva. Iako je Pokondirena tikva prevashodno komedija karaktera, s ciljem da deformisanu strast za „noblesom“ podvrgne ruglu i dovede do besmisla i apsurda, ona istovremeno govori o konkretnoj društvenoj realnosti s početka XIX veka u ondašnjoj južnoj Ugarskoj. Jezik kojim govore Sterijini likovi možda je arhaičan iz današnje perspektive, ali su zato „pokondirenost“ jezika i likova, aspiracije ka društvenom statusu elite i lažno predstavljanje - teme koje su aktuelnije danas nego što su to bile u Sterijino vreme. Satirična značenja transgresiraju istorijsko-vremensku i geografsko-lokalnu determinantu literarnog teksta ka vremenu čitaočeve recepcije dela.

Sterija oslikava provincijsku zajednicu formirajući dva „tabora“. Prvi tabor čine glavni protagonisti i zastupnici ideje o „noblesu“: primitivna opančarska udovica Fema, slavjanski pesnik i filozof Ružičić i čankoliza Sara. Drugi tabor čine sporedni, ali veoma bitni likovi koji su „glas razuma“ u komediji: Femina kćerka Evica i njen verenik Vasilije (kalfa Feminog pokojnog muža), Femina sluškinja Ančica i šegrt Jovan, kao i Femin brat Mitar. Mitar je lik čija je funkcija izrazito didaktička, moralno-vaspitna i najmanje uverljiva, ali je sa stanovišta glavne namere pisca preko potrebna i može se, uslovno rečeno, smatrati piščevim alter egom.

Početna Femina sentenca: „Opet ti kažem devojko, ja hoću nobles u mojoj kući“, instantno karakteriše Femin profil; od nje pa do kraja komedije Sterija plastično slika lice karakteristične društvene pojave - snobizma. U tom cilju služi se dramskim postupkom karakterizacije kroz dijalog dva lica na sceni, izbegavajući suvišne zaplete i ubrzavajući tok radnje. Naročito je karakteristično odsustvo monologa koji se u klasičnoj dramaturgiji smatra najfunkcionalnijim sredstvom psihološkog kreiranja lika. U Sterijinoj komediji nema ni masovnih scena, pa se svi ključni događaji odvijaju u kamernoj, intimnoj atmosferi „između četiri zida“. Na taj način društvena zajednica i njen odnos prema Feminom snobizmu ostaju „spolja“ u odnosu na radnju, materijalizujući se uvek iznova iz ugla konceptualnog sveta gledaoca/čitaoca. Tek se u završnoj sceni pojavljuju svi likovi komedije, od kojih je jedan Femin brat Mitar, moralni sudija.

Kao svojevrsnu opoziciju Femi, Sterija postavlja u prvom činu tri lika: Evicu, Vasilija i Saru. Klasičan zaplet izostaje, a nadomešću- 
je ga usložnjavanje odnosa likova, koji kroz dijaloge otkrivaju svoje društvene uloge: ulogu majke i gazdarice/udovice u porodici iz zanatlijskog staleža, ulogu pokorne kćerke $u$ patrijarhalnoj porodici i ulogu kalfe i šegrta u klasnohijerarhijskom građanskom društvu XIX veka. Istovremeno, kroz dijaloge se kristališe i odnos protagonista prema gazdaričinom porivu da „tera modu“. U dijaloškim scenama Femin like je iznijansiran $u$ rasponu od proste, vulgarne žene u sceni sa Evicom, preko autentičnog lika opančarice u dijalogu sa kalfom Vasilijem, do žene koja je „težnjom od sebe veća “6 u sceni sa Sarom.

Srž komike Sterijinog teksta lociran je u „personalnom izražavanju“ (Klajn 1958, 235), odnosno u samom Feminom i Ružičićevom govoru u svojevrsnoj rodnoj, ženskoj i muškoj pokondirenosti. Femin govor obeležavaju iskvareni nemački i francuski izrazi, koji $\mathrm{u}$ kombinaciji sa vulgarnim izražavanjem jedne opančarice stvaraju sočnu verbalnu komiku. S druge strane, Ružičić, tobož filozof, a zapravo pesnik-hohštapler i varalica koji se obraća školovanijoj publici, nakaradno koristi „crkvenoslavjanski“ jezik. Time se u opoziciju postavljaju zapadni i istočni kulturno-jezički modeli XIX veka. U teorijsko-kritičkim analizama Sterijinog dela može se naići i na mišljenja da je kroz Ružičićev lik pisac ismevao „pseudo-klasičnu književnu školu, odnosno njene sledbenike u nas, njihov pesnički ideal koji je visokoparna teatralnost, mutnu simboliku iz klasične mitologije i ruskoslavjanski jezik“" (Radonjić 2003). ${ }^{7}$ Ružičićev lik se, poput Feminog, takođe oblikuje kroz dijaloge sa drugim protagonistima i njihovim reakcijama na filozofove jezičke egzibicije.

Ostali likovi komedije su tako izgrađeni da ponašanjem i postupcima u susretu sa Femom i Ružičićem doprinose razotkrivanju pravih osobina glavnih protagonista. Uticaj komedije del arte, osim u kamernosti scene, možda se najviše primećuje u samim tipovima likova: Fema kao roditelj (vecchi), Evica i Vasilije kao ljubavni par (innamorata) i Ančica i Jovan kao sluge (zanni). Ružičić, kao kvazifilozof i pesnik, a opet i lovac na status, poseduje mešavinu karakteristika likova kao što su Doktor (il Dottore) i Pantalone (Pantalone). U komadu nema konkretnog prerušavanja kao u komediji del arte, ali se u Sterijinom realističkom postupku likovi kao Fema, Ružičić i Sara ipak izdaju za ono što zapravo nisu.

\footnotetext{
${ }^{6} \mathrm{U}$ pitanju je stih iz Sterijine pesme Čovek: „Čudno stvorenje s malom snagom i željam' ogromnim / S pedi života merom, težnjom od sebe veći“ (Hristić 2005).

${ }^{7}$ Smatra se da je direktna meta, putem parodije, bio Dositej Obradović (Radonjić 2003).
} 
Tekst Sterijine komedije, možemo da konstatujemo, satirična je kritika društva koja provocira sledeće binarne opozicije: privatno (lično) - javno (društveno), aristokratija (nobles) - građanstvo (plebs), sakralno - profano, lažno - istinito. Kao u svakoj satiri, kritička oštrica pogađa oba pola ovih parova; podsmeh je podjednako na strani svih aktera u drami, kao i na liniji pisac - čitalac.

Libreto Huga Klajna za Logarevu operu prilagođen je operskoj dramaturgiji, a da pritom ne narušava Sterijin specifičan dramaturški koncept: uveden je hor, dodati su neki stihovi za arije, redigovani su dijalozi, a ključna promena u odnosu na Sterijin tekst je izmeštanje Mitrovog monologa na sam kraj opere, čime se postiže efikasnost razobličavanja i raskrinkavanja likova. Dramska koncepcija je klasična: prvi čin ima ulogu ekspozicije likova, u drugom činu dolazi do razvoja situacije i zapleta (pojavom Ružičića i preusmerenjem njegovih bračnih namera sa kćerke na majku; zatim prodajom burmutice - inače Feminog poklona „mladoženji“ - u kojoj se nalazi Vasin lutrijski tiket, uz pomoć kojeg će steći novac, a samim tim i dozvolu da se oženi Evicom), dok treći čin razotkriva nesporazume, prave identitete Sare i Ružičića, a Femu odvraća od noblesa, te tako daje rasplet drame u maniru happy end-a, tako karakterističnog za komediju. ${ }^{8}$

Logar je, prepoznavši okosnicu komičnosti Sterijinog komada $\mathrm{u}$ jezičkim kalamburima i tipovima govora njegovih likova, svojom muzikom vešto podupirao tekst, $\mathrm{u}$ izvesnim aspektima čak nadomešćujući ono što su njegove nedostajuće komponente: gradaciju Femine ostrašćenosti skoro do ludila i odnos društva prema Femi. Žižne tačke Logareve opere pozicionirane su u arijama, $s$ tim što kompozitor ne koncipira arije u sasvim tradicionalnom smislu. One su često isprekidane dijalozima učesnika, prerastaju na momente $u$ duete ili tercete $i$, neretko, bivaju uzglobljene na način koji obezbeđuje dinamičnost i prohodnost dramskog događanja. Iako u operi nema lajtmotiva, „spiralno“ sprovođenje nekih motiva iz arija obezbeđuje povezanost muzičkog toka i kratke reminiscencije na prethodna scenska događanja.

\footnotetext{
${ }^{8}$ Ova je izmena bila nužna, prema rečima Huga Klajna, zbog specifičnosti, odnosno ambivalentnosti Sterijinih komedija (ili tragikomedija). „Sterijini završeci su gotovo uvek obojeni nekom setom, u završnom akordu ima redovno i jedan disonantan ton“ (Klajn 1956, 239).
} 


\section{Muzički humor u operi Pokondirena tikva}

Muzički jezik opere je umereno moderan; savremen, ali nepretenciozan. Mekši je i manje harmonski disonantan nego što je bio u prvoj Logarevoj stvaralačkoj fazi, po kompozitorovom dolasku $\mathrm{u}$ Beograd. Vokalne deonice $\mathrm{u}$ arijama i recitativima $u$ potpunosti su podređene razumljivosti teksta i fleksijama govora. Orkestarska pratnja je, s druge strane, ilustrativna i sugestivna; orkestar je taj koji stvara štimung, dočarava situacije i komentariše ih. Obilje sitnih muzičkih gestova, parodije konvencionalnih muzičkih topika (kao što su trijumfalni marš ili igre), efektno upotrebljenih disonanci ili ukrasa, iznenadnih cezura, diskontinuiteta muzičkog toka (koji je pretežno con brio) ili promene afekta - sve to spada u arsenal Logarevih humornih tehnika.

U skladu sa Sterijinim konceptom psihološkog ocrtavanja Feminog karaktera u prvom činu drame, Logar je početni čin opere, inače znatno duži u odnosu na drugi i treći, realizovao nizom scena u kojima Femin lik skicira kroz odnose sa ostalim protagonistima. Svoj san o noblesu Fema isprva saopštava Evici u ariji sa zvoncetom (partiturni broj 28). Statusni simboli visokog staleža iz Femine vizure - zvonce i lepeza - muzički su ilustrovani odgovarajućim motivima ikoničke srodnosti: zvonce - tremolom violina i tercnim grupetima flauta u visokom registru, a lepeza - ritmizovanim motivom velike terce $\mathrm{u}$ deonici solo violine i na fonu prekomernog trozvuka harfe. Komika melodije („Znaj da nobles pravi kiti se i beli i trinkelte deli i haljine bira i francuski parlira i kosu frizira") zasnovana je na tendencioznim sekvencama motiva naviše po sekundama, čime se podvlači nabrajanje osobina noblesa i kulminacija na rimovane reči „parlira“ $i$,frizira“. Ovi galicizmi markirani su bogatim ornamentima i trilerom u pravom bufo stilu. Između nakićenih refrena Fema grdi Evicu („drnda, sluta, prava krava“), prelazeći naglo sa „noblesnog" na vulgarni govor, što Logar muzički realizuje prelaskom sa melizmatične melodijske konture i tročetvrtinskog takta na skandirajući parlando u parnom taktu. Živopisna Logareva orkestracija pruža snažnu podršku burlesknim obrtima, kako u ovoj ariji, tako i u celoj operi. Orkestar trojnog sastava sa većim brojem udaraljki nijednog trenutka ne pokriva glasove, ali stvara štimung i komentariše tekst. Tako u ovoj ariji, osim pomenutih ikoničkih znakova lepeze i zvonca, karakterističan je „srebrnasti“ zvuk harfe sa efektnim glisando završnicama fraza; kratke ritmičko-melodijske figure izvedene iz melodije refrena mogu se čuti u deonicama drvenih duvačkih instrumenata (flaute, oboe i klarineti), a brojni ukrasi im 
daju humorni karakter. I dok violine pružaju harmonsko-melodijsku i intonativnu potporu vokalnoj deonici (sa povremenim picikato efektima i imitacionim ponavljanjem motiva), viole, violončela, kontrabasi i horne održavaju ritmički valcersko-lendlerski puls.

Poenta prvog čina locirana je u razvijenoj sceni dolaska Sare (Gavotta - Allegretto sostenuto e buffo, partiturni broj 43). Muzički obrazac gavote ovde je plasiran kao indkesični znak francuskog kulturnog modela. Igra je nestala u Parizu početkom XIX veka, te je tako u vreme o kojem Sterija piše i u kojem se radnja komedije događa već bila passé. Jezički kalamburi, od Sarinog pitanja: „Vi kec?“ (nemački: Wie geht's? / Kako ste?) do čuvenog „komi fo“ (francuski: comme il faut? / Kako treba?), koji Fema ne može da zapamti, pa ga prekraja u - „mikofo“, kao i Sarin euforični izveštaj o tome šta je sve jela kod „gospoje Mirkovićke“, Logar vrlo plastično ilustruje prateći fleksiju reči, uzdahe pune čežnje i divljenja. Humor počiva na semantičkoj neusaglašenosti gracioznog karaktera gavote i trivijalnog teksta; slično već opisanom postupku u Feminoj ariji, Sarina deonica prelazi u parlando, a persiflaže ima u staccato melizmima i u čestim cezurama, koji, združeno, ostvaruju efekat Sarinog uzbuđenog i izveštačenog govora. U persiflaži učestvuje i orkestar, koji na momente suptilno prokomentariše radnju glisandima, a u prvi plan neočekivano izbija $u$ trenutku Feminog šepurenja novim loknama pred Sarom (Espressivo e largamente assai, partiturni broj 49), tumačeći temu gavote u malerovsko-štrausovskom, tužno-smešnom maniru: $\mathrm{u}$ forte dinamici, $\mathrm{u}$ neopredeljenosti između dura i mola, $\mathrm{u}$ umornom tenuto naglašavanju arze $u$ deonici fagota $i$ trombona, $u$ ehu submotiva gavote $u$ pikolo flauti i trubi i tendenciji usporavanja. Kao da se kompozitor i sam u tom trenutku zapitao: ima li kraja ovoj farsi? Centralno ironijsko i kulminaciono mesto čina događa se u momentu kada Sara provodadžiše Evici („hipš frajlici“) izglednog mladoženju - „filozofa od karaktera“. U tom trenutku Logar napušta ritam gavote, postepeno reducira učešće orkestra do potpunog ukidanja zvučne podloge. Femino pitanje, izgovoreno s nevericom - „filosof!?“ - ilustrovano je tritunosnim skokom. U ovom ključnom dramaturškom obrtu uslediće komentar orkestra: tuba solo svira u forte dinamici najdublji ton svog opsega kontra Es (!), ${ }^{9}$ uz podršku bubnja i tam-tama, čiji je odjek teskoban i zastrašujući. Ovaj momenat je lociran otprilike na mestu zlatnog preseka prvog čina i Logarev potez litote je muzički gest kojim se postiže snažan efekat

\footnotetext{
${ }^{9}$ Kontra $E$ je najdublji ton tube, te tako postoji velika mogućnost da pikirani ton kontra Es bude pogrešno odsviran, naročito u forte dinamici.
} 
sarkazma. Pritom, koristi dva muzička simbola - tritonus u Feminoj deonici kao raspolućenje tonaliteta, i najnezgrapniji instrument koji orkestar poseduje. Ali, kad se Fema oporavi od prvobitnog šoka, gavota se nastavlja u ubrzanom tempu, projektujući Feminu viziju blistave budućnosti („grofice, baronice, preda mnom će puziti“).

Do kraja prvog čina uslediće niz mini scena-dijaloga Feme sa ostalim akterima komedije u manje-više sličnom karakteru igre. Humorni ton je prisutan konstantno, jer ga produkuje sam tekst. Fema odbija da je zovu majstoricom jer je sad „frau fon gospoja“, mada se nikako ne može setiti kako se to kaže na francuskom. No, i kad se seti, zajedno sa otmenim izrazom, omakne joj se uzrečica koja joj jeste prirodna („najveće madame - madame, vrag im materi, nisam mogla otoič pogoditi“). Uslediće prepirka sa Jovanom i duet Feme i Ančice, u kojem služavka daje savete svojoj gospodarici o tome „kako se nobles unterlondruje“. Taj lendler, malerovsko-štrausovskog tipa po orkestraciji, specifična je parodija na operske duete (Sempre lo stesso tempo, partiturni broj 79). Lendlerska tema u orkestru ponavlja se varirano pet puta; specifičnu boju melodije ostvaruju visoke violine udvojene u oktavi, picikato naglasak (kontrabas col legno!), dok se kontrtan efekat ostvaruje združenom bojom zvona i harfe na nenaglašenim taktovim delovima. Na ovom fonu se odvija i dija$\log$ Feme i Ančice. Ančica se ironično, napadno snishodljivo obraća „milostivoj gospoji“ $u$ karikiranom koloraturnom stilu. Ritmički isprekidana vokalna deonica sa upadljivim forsiranjem graničnih tonova sopranskog registra $\left(\mathrm{c}^{3}\right)$ predstavlja parodiju na bravure koloraturnih sopranskih deonica. Posebno dolazi do izražaja u trenutku kad Ančica Femu obaveštava da nobles gospoda uglavnom „u fortepjano udaraju“. Srednji odsek valcera („da mi kupiš tri drombulje da se nobles unterlondruje“), $\mathrm{u}$ kojem se dve vokalne deonice pretežno kreću u paralelnim tercama i sekstama, na fonu romantičarskih harmonija, lako uspostavlja asocijativnu vezu sa italijanskom operom i Verdijevim duetima. Parodijski momenat je i kvazionomatopejsko označavanje drombulja, koje svojim neprikladnim „tu-tu“ više asocira na, kontekstu takođe neodgovarajući, pastoralni „ku-ku“. Ovim kalamburskim „bisociranjem“ ostvaruje se snažan komičan efekat, koji se, u krajnjoj konsekvenci i kontekstu vremena u kojem je opera nastala, može tumačiti i kao parodijska kritika na repertoarsko favorizovanje italijanske opere na domaćim scenama.

U drugom činu dolazi do zapleta koji afirmiše i druge vidove komičnog, kao što je recimo groteska. Femina ostrašćenost dobija na intenzitetu i to je primetno već u numeri sa Jovanom, u okviru ko- 
je je i Femina arija „Iz Pariza dolazi bonton, ah, francuski je moj pasjon!" U ovoj ariji ona kombinuje, bez ikakvog reda i smisla, ono malo francuskih reči koje misli da zna: „satunder“, „božur“, „mikofo, „propopopo“, „saprbu madam“, „les nobles“, „les tružes“ itd. Između refrena, ona pokušava Jovana da nauči francuskim rečima (što rezultira dodatnim jezičkim kalamburima), traži od njega da joj kupi „lamura“ (misleći pri tom na psa), sanjari o udaji svoje kćeri za filozofa i kakvu će time dobiti „propusnicu“ za visoko društvo. Trijumfalno zaključuje „divit’ će se Femi ceo svet“. U tom emfatičnom trenutku ona ne govori više u prvom licu, a u muzici je to propraćeno pojavom toposa trijumfalnog marša. Signaliziran je metričkom promenom, fanfarnim motivom u trubama i forte nastupom limenog duvačkog korpusa (oznaka Trionfale, ispred partiturnog broja 24). Poslednji refren se izvodi dva puta sa euforičnom kulminacijom ponovljenih izraza $u$ isto tako euforičnoj melodijskoj liniji, sa opštom tendencijom agogičkog ubrzanja (Accelerando. Piu vivo) i odzvucima toposa trijumfalnog marša u trubama, trombonima i dobošu. Kombinacija toposa - skercoznog i marševskog, besmisleno nabrajanje i opsesivno ponavljanje reči „madam“, euforična agogika, a prevashodno neurotično skokovita i ritmički pokretljiva vokalna deonica - sve je to u službi dovođenja Feminog „pasjona“ do granice ludila. Ova arija je egzemplifikacija groteske (kao hibrida smešnog i strašnog) u Logarevoj operi. Opsesivno ponavljanje, koje inače nije svojstveno dramskom tekstu, barem ne onom Sterijinog doba, u muzici je moćno sredstvo realizacije raznolikih efekata. U ovom slučaju, Logareva partitura nudi izvesnu nadgradnju psihološkog profila Sterijine Feme, te predstavlja momenat o kojem bi reditelji morali da vode računa $u$ eventualnim budućim postavkama opere. ${ }^{10}$

Introdukcijom Ružičića $u$ drugom činu, dramski akcenat se $u$ izvesnoj meri pomera sa Feme na samozvanog filozofa i pesnika, čija je prva sentenca na sceni u maniru patetičnih idilično-romantičarskih stihova: „Nebo grmi, zemlja strepi, slavuj peva, ševa trepti..." (partiturni broj 30). Od tog trenutka nadalje, metro-ritmička organizacija muzičkog toka prilagođava se Ružičićevim jezičkim, izvitoperenim obrtima slavjanoserbskog jezika; silabična melodija, neretko modalno obojena, asocira na crkvene napeve. U Sterijinim komedijama slavjanoserbskim_jezikom se služe varalice, probisveti i fantasti, koji time pokrivaju svoju prevrtljivost. „Pokondirenost“ Ružičićevog govora ima, dakle, drugačije jezičko ishodište, ali je

\footnotetext{
${ }^{10}$ Ovo naglašavamo zbog rediteljskih skraćenja opere u dosadašnjim izvođenjima. Završni segment Femine arije ne nalazi se na snimku opere u posedu Radio Beograda.
} 
predmet podsmeha $\mathrm{u}$ istoj meri $\mathrm{u}$ kojoj je to i pokondirenost Feminog govora.

Paradigmatični primer ozbiljno-patetičnog karaktera Ružičićeve melodijske linije možda se najbolje ocrtava u egzaltiranoj sentenci „Svakom svoje, moja je slava stihotvorstvo moje...“ (drugi čin, partiturni broj 40). Književni kritičar Milan Tokin u Ružičićevom „stihotvorstvu" lucidno prepoznaje Sterijinu parodijsku aluziju na poeziju Dositeja Obradovića (Tokin 1956). U odnosu na deonice ostalih protagonista, Ružičićev vokalni part pokazuje distinktivna obeležja: postepeno melodijsko kretanje oslobođeno nezgrapnih skokova i ukrasa, sporiji ritmički tok, bez kapricioznih figura i čestih pauza. Dugi, izdržani tonovi u visokoj baritonskoj lagi (ton $\mathrm{f}_{1}$ ), silazno kretanje po tonovima eolskog mola, kao i kvartni skok naniže (iz tonike u dominantu) daju Ružičićevoj deonici posebnu notu uzvišenosti i autoriteta. Orkestar dodatno pojačava taj utisak udvajajući početak sentence, a zatim i dramatičnim tremolima u gudačkom korpusu. U realizaciji same vokalne deonice nema ničeg eksplicitno komičnog; komentar daje orkestar, koji, poput antropomorfiziranog tela, karikira pompezne motive filozofa (limeni duvački instrumenti), podsmeva mu se (ornamentiran motiv u flauti pikolo, oboi i harfi) i kikoće se umesto publike. Ružičićeva vokalna linija dobija komično značenje tek $u$ kontekstu, $u$ direktnom sučeljavanju sa vokalnim deonicama drugačije izražajne provenijencije ili, kao u poslednjem navedenom slučaju, kao predmet poruge orkestra.

Sintagmatske inkongruencije postaju osnovno sredstvo komike $\mathrm{u}$ drugom činu. One se, $\mathrm{u}$ daljem toku, manifestuju prvenstveno $\mathrm{u}$ dijalozima Ružičića sa Evicom i Jovanom. Scena sa Evicom (arija „Šta je život bez ljubavi?“, partiturni broj 54) građena je u smeni filozofovih egzaltiranih, patetičnih tirada, opterećenih epitetima i metaforama, i Evičinih kratkih pitanja. Kako je ljut zbog nerazumevanja na koje nailaze njegove pesničke metafore, uslediće epizoda koja je pandan onoj euforičnoj Feminoj iz prvog čina. Uz fizičke gestove približavanja Evici i unošenja u lice (verbalna napomena u Logarevoj partituri!), ostvaruje se kulminaciona tačka dramskog toka koju će Evica, u svojoj prostodušnosti, okončati kratkom konstatacijom: „Eh, koješta!“ Komičnost ove scene najbolje i najkonciznije može se opisati Kantovim određenjem humora kao „hitrog preoblikovanja tenzije iščekivanja u ništa“.

Kao i u prethodnom primeru, primarna komika Ružičićeve čuvene arije „Velkomožni trbuve“ počiva na sučeljavanju različitih tipova ekspresivnog sadržaja. Početak arije je sasvim u duhu Ružičićevog 
razvučenog i modalno obojenog muzičkog govora. No, inkongruencija se odmah obrazuje između karaktera muzike i samog teksta; isti onaj poeta koji je do malopre ubeđivao Evicu kako je poezija jedina njegova hrana, sada peva odu trbuhu, čije „silne meuve, gladnoga gone pevati, gone stihe praviti“. Orkestar je i ovde, kao i u prethodnom primeru, glavni komentator; efekat provale smeha ostvaruju glisanda limenih duvačkih instrumenata (horne, trube, tromboni) i harfe, potpomognuti staccato tonovima sa šlajferima u violinama i flautama (partiturni broj 81). Srednji odsek arije je lirska fraza na modalnoj osnovi („zbog tebe lepe devojke za starkelje polaze“), a uslediće ljutiti parlando accelerando („lepi mladići babuskere uzimlju“). Arija se završava onako kako je i počela - sa dramatskim nabojem, koji je rezultat višestruko augmentiranog početnog motiva u forte fortisimo dinamici, sa akcentovanim tonovima i glisandiranim uzdahom na kraju. Ova arija je istovremeno značajan dramaturški punkt i u Sterijinom tekstu i u Logarevoj operi jer označava početak demaskiranja likova. Naime, ovo je prvi monološki nastup poete (svi prethodni su bili dijaloški) $u$ kojem je primetno napuštanje dotadašnjeg lingvističkog koda Ružičićevog govora - nagli prelaz sa slavjanoserbskog, učenog, visokojezičkog koda na vulgarni, pejorativni ili niskojezički kod (euforično ponavljanje reči kao što su „babuskere“ i „starkelje“) analogan je postupku primenjenom u Feminoj „ariji sa zvoncetom "u prvom činu. Drugim rečima, ova arija prvi put aktivira recipijentovu sumnju u autentičnost pesnikovog lika, a istovremeno dovodi u istu parodijsko-ironičnu ravan Ružičićev pesnički „stoicizam“i Feminu hedonističku pomodnost.

U svakom činu postoji najmanje jedna markirana igra; ako je to u prvom činu bila gavota, $u$ drugom činu je to polka. Preuzimanje igračkog modela polke inicirano je gestom „nesporazuma“ između Jovana i Ružičića. Jovan misli, na osnovu pesnikovog govora da je ovaj Slovak, te komunicira s njim koristeći nekolicinu izvrnutih slovačkih izraza (partiturni broj 25). Prijemčiva melodija i prepoznatljiv ritam polke diskretno su karikirani orkestracijom. Aluzija na bleh-muziku polki postiže se putem ritmičko-harmonske pratnje (po principu bas-akord); pojačana uloga duvačkog korpusa i udaraljki, uz čitav arsenal ukrasa, grupeta, šlajfera i predudara, opet stvara asocijacije na malersko-štrausovska skerca.

U trećem činu je koncentrisan niz numera, od kojih je, po načinu realizacije komičnog, najzanimljivija ona kojom započinje taj čin. To je Ančicina arija („Ova naša Fema“), u kojoj je lociran odjek motiva iz istoimene horske numere s početka drugog čina. Osim toga, 
Ančica ironijski imitira (parodira) Femine izraze („božur“, „lamur“, „il mamicken“, „il mama“....). Ovi momenti u ariji su markirani tenuto tonovima, promenama agogike i oznakom espressivo.

Posebnu komiku u ariji ostvaruju melizmi (parlando staccatissimo) u brzom tempu, ponavljanja delova fraza i čak sedamnaest taktova izdržanog tona $c^{3}$ ! Numere koje slede nižu se po principu kontrasta, ali je svima zajedničko muzičko-semantičko markiranje romantičarske tradicije. Evicina arijeta „Cvetance moje“ aludira na tip srpskog romantičarskog lida, kao uostalom i Vasina arijeta o Evici. U odnosu na prethodan izbor igara, koje su označavale zapadnu kulturu, plasiranje bećarca u Vasinoj numeri sa Evicom, a naročito ponovna pojava bećarca na samom kraju opere, nosi predznak nacionalnog, pa time i značajnu semantičku i didaktičku poruku Sterijinog teksta.

\section{Kritički osvrt na recepciju Logareve opere}

Podsmeh na račun „noblesa“, crkve i zapadnoevropskog aristokratskog kulturnog modela, bilo je $\mathrm{u}$ vreme prvog izvođenja Logareve opere na liniji posleratne socijalističke dogme, pa samim tim i društveno prihvatljiv. No, kako oštrica satire nije upućena samo na jednu stranu, tako je slučaj i sa Pokondirenom tikvom; satira se okreće i prema protagonistima i prema autoru, prema publici i celom društvu, zavisno od toga ko, iz koje perspektive i sa kojim motivima tumači satiru. „Prosvetitelj Sterija hteo je da leči antropološke konstante kojima nema leka. Fema, Ružičića i 'rodoljubaca' i danas je puna Srbija, uprkos tome što se Sterijine komedije igraju na našim scenama. Isto tako, pun ih je svet i mogu se naći, u malo izmenjenom lokalnom kontekstu, u svim antologijama komedije raznih naroda“" (Milutinović 2007, 83). Tako se Sterijin tekst u Logarevoj interpretaciji, a u vreme nastanka i prvog izvođenja opere, mogao alegorijski razumeti i kao kritika posleratnog društvenog stanja, kada su zaslužni ratni borci, kao nagradu za odanost partiji, dobijali konfiskovanu imovinu predratne građanske klase, pa se i sami „pokondirili“. Takođe Sterijino ismevanje pokondirene Femine i Ružičićeve retorike alegorijski se moglo tumačiti i kao kritika marksističke retorike političkih govora. Kako su muzičke kritike uglavnom bile pozitivne, a Logarev humor ocenjen kao dobroćudan, verovatnije je da političkog podteksta nije bilo. Polovinom prošlog veka još uvek je postojala recepcija komičnog žanra kao „nižeg“ i umetnički manje vrednog u odnosu na tragediju. „Držanje 'neozbiljno'“, kako Zofija Lisa definiše humor, naročito u muzici, ima manje povoljan status 
(Lissa 1977, 96); psihološki kompleksni likovi, dramatični obrti u radnji, tragične sudbine i savremena tematika izazivaju više empatije publike. Na to ukazuje i repertoarska politika institucija kojom se kod publike negovala sklonost ka ozbiljnom dramskom izrazu, a pritom i klasičnom italijanskom operskom repertoaru. U takvom kontekstu, Logareva Pokondirena tikva nije mnogo ni stilski ni dramaturški uzburkala očekivanja operske publike.

Ni komične opere koje su usledile šezdesetih godina, Majstori su prvi ljudi Dušana Kostića (1962) i Ljubav, to je glavna stvar Dušana Radića (1963), nisu opstale na repertoarima domaćih operskih scena. Tome je doprinelo više razloga. Prvo, visoka kultura i institucije u kojima ta scena živi, kao što smo naglasili, nisu imali sluha za humor i sklonosti ka muzičko-komičnom žanru. Sve tri opere su plasirane $\mathrm{u}$ vremenskom periodu obeleženom kontrolom produkcije i u smislu izbora tematike i u umetničko-izražajnom smislu. Ono što je šira kulturno-društvena praksa podržavala - pojednostavljen izraz i komunikativnost muzike pre svega - odavno je u operskom žanru bilo prevaziđeno. Kriza opere je bila zvanično deklarisana. S druge strane, rastući značaj mjuzikla u svetu, kulturni bum rokenrola, prodor američkog uticaja, a naročito pojava novog medija - televizije tokom 60-ih godina, ${ }^{11}$ pomerili su interesovanja publike i poklonika lakšeg i duhovitijeg žanra ka zabavnoj muzici, televizijskim šou programima i adaptacijama američkih mjuzikla u Humorističkom pozorištu, osnovanom 1949. godine..$^{12}$ Ostale umetnosti, naročito književnost i slikarstvo, beleže u Srbiji tokom XX veka snažan procvat humorističkih žanrova, kako onih „viših“ (komedija, satira, humoristička poezija, pripovetka itd.), tako i „nižih“ (aforizmi, vicevi, anegdote, karikatura). Iako ne treba zanemariti za humor nepovoljno „stanje duha" $u$ doba svetskih ratova, nedostatak humora u muzici možda treba tražiti na drugoj strain, odnosno u posebnim mehanizmima funkcionisanja svake umetnosti ponaosob, a time i muzike u specifičnim kulturnim kontekstima prve polovine veka. Treba imati u vidu da srpska muzika nije imala tako dugu i kontinuiranu tradiciju kao književnost ili slikarstvo. Ključne institucije za muzičku produkciju i reprodukciju su osnovane tek u međuratnom

\footnotetext{
${ }^{11}$ Televizija Beograd je eksperimentalnim prenosom sa Sajma zavanično započela svoj rad 23. avgusta 1958. godine.

12 Pozorište je osnovano kao stalna repertoarska ustanova pozorišne kulture, muzičkog i komedijskog žanra. Od 1954. do 1959. godine zove se Beogradska komedija, a spajanjem sa Beogradskim dramskim pozorištem 1959. godine dobija ime Savremeno pozorište. Godine 1975/76. ustanova postaje samostalna i dobija sadašnji naziv - Pozorište na Terazijama.
} 
periodu. Dolaskom generacija kompozitora školovanih $u$ inostranstvu stvoreni su uslovi za podizanje profesionalnog nivoa, kako $u$ oblasti muzičkog stvaralaštva i izvođaštva, tako i u oblasti pisane reči o muzici. Potreba da se uspostavi veza sa tekovinama srpske muzičke tradicije, a istovremeno i prisnija veza sa savremenim evropskim tokovima i modernizacijom jezika, kao i odgovornost za formiranje ukusa i svesti domaće publike odredilo je poziciju generacija kompozitora koja je $\mathrm{u}$ datim kulturnim okolnostima dominantno negovala „držanje ozbiljno“. ${ }^{13}$ Imajući u vidu subverzivnu dimenziju humora i kritički stav koji podrazumeva, Logarev muzički jezik, duhovit, kapriciozan i slobodan od stilskih stega i normi, verovatno i nije mogao naići na prisniji odziv u srpskom građanstvu patrijarhalnog mentaliteta. Osnivanje pomenutog Humorističkog pozorišta označilo je institucionalizovanje onog muzičkog žanra koji se u modernističkim okvirima smatrao „nižim“, a to je mjuzikl. Time je i granica između „ozbiljnog “ $i$ „neozbiljnog“ repertoara bila jače utvrđena.

Sindrom opere kao nedovoljno prihvaćenog žanra u srpskom kulturnom i umetničkom kontekstu svojevremeno je najprikladnije objasnio kompozitor Dušan Radić: „Opera je danas nezahvalna zamisao: ako je složena - ne vole je izvođači, ako je laka i jednostavna - spada u operetu, ako je novatorska - ne voli je publika, ako je staromodna - ne vole je napredniji krugovi, a nadobudna kritika je pretvori u rezance. $U$ operi treba pevati, a ne mukati, grgotati i deklamovati. Teško je pronaći zlatnu sredinu. Ako je neko i pronađe, pronašao ju je nizašta“" (Jevtić 2003, 32).

Činjenica da su se komedije Trifkovića, Sterije i Molijera zadržale na beogradskim pozorišnim scenama do današnjih dana, a da scenska dela naših kompozitora pisana na iste tekstove tih komedija - nisu, govori da je u slučaju ovih drugih postojao, s jedne strane, loš tajming, a s druge strane - odsustvo dugoročne zajedničke strategije nacionalnih institucija u negovanju (komične) opere. Za poklonike i pobornike visoke muzike - ona su bila suviše prijemčiva i, budući bazirana na tradicionalnim modelima, sasvim passé, dok su za sledbenike nadirućeg talasa popularne muzike bila suviše artificijelna. Pokušaj televizijske adaptacije komično-scenskih dela kao što su opera balet Stav'te pamet na komediju Nikole Hercigonje iz 1973. godine i Paštrovskog viteza Mihovila Logara iz 1983. godine ${ }^{14}$

\footnotetext{
${ }^{13}$ Misli se prevashodno na Konjovića, Hristića i Milojevića, a potom i na praške đake.

${ }^{14}$ Logar je operu završio 1974. godine, a snimljena je tek devet godina kasnije.
} 
nije imao boljeg efekta na širu publiku, ali je zanimljiv kao pokušaj revitalizacije opere u drugom, sinkretičkom mediju. Ne možemo a da ne primetimo da je tematika ovih komičnih opera vezana za prošlost i da bi to mogao biti još jedan od razloga što u veku koji su humorom obeležili mnogi domaći pisci pišući o savremenom dobu nisu uspele da se trajno zadrže na repertoarima (Vuksanović 2016).

Treba naglasiti da se krajem prve decenije ovog veka na srpskoj muzičkoj sceni revitalizuje komični muzičko-scenski žanr. Za samo deset godina nastale su četiri komične opere: Zemlja sreće (2007), opera satira Vladimira Pejkovića, Maratonci (2008), tragikomedija Isidore Žebeljan, Mandragola (2009), opera farsa Ivana Jevtića, i Pop Ćira i pop Spira (2018) Dejana Despića. Verujemo da u ovakvim okolnostima - uz dobar marketing, režijsko osavremenjivanje, pažljivo redigovanje i adaptaciju originalne partiture, brižljiv izbor izvođača i moderniju inscenaciju - Logareva Pokondirena tikva mora ponovo oživeti na sceni, ako ne u okviru stalnog repertoara, onda makar kao postavka koja će, zarad kulture sećanja, biti digitalizovana u audio-vizuelnom formatu.

Literatura

Hristić, Jovan. 2005. „Sterijina poezija“. U Izabrani eseji. Beograd: Srpski PEN centar.

Jevtić, Miloš. 2003. Svet muzike. Razgovori sa Dušanom Radićem. Beograd: Beogradska knjiga ; Valjevo: Kej.

Klajn, Hugo. 1956. „Sterijin humor“. U Knjiga o Steriji, ur. Branislav Miljković, 221-251. Beograd: Srpska književna zadruga.

Kozina, Marjan. 1957. „Pokondirena tikva Mihovila Logara“. Zvuk 9/10: 381-384.

Lissa, Zofia. 1977. Estetika glazbe. Zagreb: Naprijed.

Ljuboja, Gordana. 2001. Etnički humor XX veka. Beograd: Etnografski muzej.

Maksimović, Goran. 2003. Trijumf smijeha. Niš: Prosveta.

Milanović, Miodrag D. 2010. Šest pisama Mihovila Logara - „Ozvučeni Sterija“. Dostupno na: https://www.rastko.rs/muzika/delo/13736.

Milin, Melita. 1998. Tradicionalno i novo u srpskoj muzici posle drugog svetskog rata (1945-1965). Beograd: Muzikološki institut SANU.

Milutinović, Zoran. 2007. „Melanholija i humor J. S. Popovića“. U Jovan Sterija Popović, ur. Ljubomir Simović, 77-89. Beograd: Srpska akademija nauka i umetnosti. 
Mosusova, Nadežda. 2008. „Komedija del arte u muzičko-scenskom opusu Mihovila Logara“. U Allegretto giocoso - stvaralački opus Mihovila Logara, ur. Roksanda Pejović, 30-35. Beograd: Fakultet muzičke umetnosti.

Pavlović, Mirka. 1982. „Mihovil Logar - Pokondirena tikva“. Zvuk 4: 57-60.

Pavlović, Mirka. 1995. „Libreto u muzičko-scenskom stvaralaštvu u Srbiji“. U Srpska muzička scena, ur. Nadežda Mosusova, 61-81. Beograd: Muzikološki institut SANU.

Pavlović, Mirka. 2008. „Iz zapisa Mihovila Logara (1902-1998)“. U Allegretto giocoso - stvaralački opus Mihovila Logara, ur. Roksanda Pejović, 4454. Beograd: Fakultet muzičke umetnosti.

Popović, Pavle. 1956. „Pokondirena tikva“. U Knjiga o Steriji, ur. Branislav Miljković, 51-59. Beograd: Srpska književna zadruga.

Radonjić, Miroslav. 2003. „Postupak karakterizacije u Pokondirenoj tikvi, Kir Janji i Rodoljupcima“. Scena 39 (1-2). Dostupno na: http://www. pozorje.org.rs/stari-sajt/scena/scena1203/9.htm

Tokin, Milan. 1956. „Vršac u Sterijinom ogledalu“. U Knjiga o Steriji, ur. Branislav Miljković, 95-136. Beograd: Srpska književna zadruga.

Vinaver, Konstantin. 1995. „Repertoarska politika Opere Narodnog pozorišta od osnivanja do danas“. U Srpska muzička scena, ur. Nadežda Mosusova, 248-268. Beograd: Muzikološki institut SANU.

Vuksanović, Ivana. 2016. Humor u srpskoj muzici 20. veka. Beograd: Fakultet muzičke umetnosti.

Zdravković, Živojin. 2008. „Mihovil Logar“. U Allegretto giocoso - stvaralački opus Mihovila Logara, ur. Roksanda Pejović, 125-140. Beograd: Fakultet muzičke umetnosti.

Ivana Vuksanović

Univerza umetnosti v Beogradu

Fakulteta glasbene umetnosti

Srbija

vuksanovici@fmu.bg.ac.rs

\section{OPERA POKONDIRENA TIKVA MIHOVILA LOGARJA IN VZPOSTAVITEV KOMIČNEGA GLASBENO-SCENSKEGA ŽANRA V SRBIJI}

Vzpostavitev glasbeno-scenskega komičnega žanra se je v Srbiji zgodila šele v drugi polovici 20 . stoletja, natančneje leta 1956, ko se je spod peresa skladatelja Mihovila Logarja (1902-1998) pojavila opera po istoimenski komediji Jovana Sterije Popovića Pokondirena tikva. S tem je bila na srbski operni sceni premoščena časovna vrzel več kot dveh stoletij, ko se je prva komična opera pojavila v Italiji. 
65 let po nastanku Logarjeve Pokondirene tikve prepoznavam pomen tega žanra za kulturno-umetniško življenje preteklega stoletja v Srbiji, stilske in dramaturške domete Logarjeve opere, zgodovino njenih izvajanj in vpliv na nadaljnii razvoj žanra v Srbiji. V članku so analitično obravnavani mehanizmi Logarjevega glasbenega humorja, s posebnim ozirom na odnos med besedilom in melodijo vokalne sekcije ter vlogo orkestracije. Kljub kompozicijsko-tehničnim in ekspresivno-humornim kvalitetam pa se Logarjevi operi ni uspelo približati domači publiki, niti prek sodobnejše režije in prilagoditev, zato v članku kritično obravnavam usodo Pokondirene tikve in njeno recepcijo v drugi polovici stoletja kot posledico repertoarne politike srbskih opernih institucij in statusa humorja v domači glasbeno-scenski recepciji.

Ključne besede: Mihovil Logar, opera buffa, Pokondirena tikva, glasbeni humor, recepcija

Ivana Vuksanović

University of Arts in Belgrade

Faculty of Music

Serbia

vuksanovici@fmu.bg.ac.rs

THE OPERA POKONDIRENA TIKVA BY MIHOVIL LOGAR AND THE ESTABLISHMENT OF THE COMIC OPERA GENRE IN SERBIA

The establishment of the comic opera genre in Serbia took place as late as the second half of the $20^{\text {th }}$ century, more precisely in 1956 , with the emergence of the opera Pokondirena tikva (A Would-be Lady), composed by Mihovil Logar (1902-1998), based on the eponymous comedy by Jovan Sterija Popović. Thus the genre appeared on Serbian opera scene, spanning the gap of more than two centuries since the emergence of the first comic opera in Italy. Sixty-five years after its establishment, it is possible to assess the significance of this genre in Serbia's cultural and artistic life in the $20^{\text {th }}$ century, the stylistic and dramaturgical range of Logar's Pokondirena tikva, the history the opera's performances and its influence on the further development of the genre in Serbia. The text analytically discusses the mechanisms of Logar's musical humour, with special reference to the relationship between the text and the melody of the vocal section, as well as the role of orchestration. Despite its compositional and technical features, on the one hand, and expressive and humorous qualities, on the other, Logar's opera has failed in gaining reception among the local audience in spite of modernized stage productions and adaptations. Accordingly, the text critically discusses the fate of 
Pokondirena tikva and the reception of this opera during the second half of the $20^{\text {th }}$ century as a consequence of the programme policy of opera institutions and the status of humour in local theatrical music performances.

Keywords: Mihovil Logar, opera buffa, Pokondirena tikva, musical humour, reception

Primljeno / Prejeto: 10. 06. 2020.

Prihvaćeno / Sprejeto: 04. 12. 2020. 